See discussions, stats, and author profiles for this publication at: https://www.researchgate.net/publication/286653125

\title{
Effect of different levels of concentrate on ruminal microorganisms and rumen fermentation in Nellore steers
}

Article in Archives of animal nutrition · January 2016

DOI: 10.1080/1745039X.2015.1117562

\section{CITATIONS}

14

8 authors, including:

Yury Tatiana Granja Salcedo

São Paulo State University (Unesp)

55 PUBLICATIONS 66 CITATIONS

SEE PROFILE

Raphael Jesus

São Paulo State University

11 PUBLICATIONS 49 CITATIONS

SEE PROFILE
Carlos Stefenson Ribeiro Júnior

São Paulo State University

17 PUBLICATIONS 42 CITATIONS

SEE PROFILE

15. Arturo Samuel Gomez Insuasti

National Open University and Distance (Colombia)

11 PUBLICATIONS 22 CITATIONS

SEE PROFILE

Some of the authors of this publication are also working on these related projects:

Riparian forest rehabilitation and integration of agricultural and forestry component for hydrological sustainability and land use in livestock farms. View project

Eficiencia alimentaria y nutrigenómica en la alimentación animal View project 


\section{Effect of different levels of concentrate on ruminal microorganisms and rumen fermentation in Nellore steers}

\section{Yury T. Granja-Salcedo, Carlos S. Ribeiro Júnior, Raphael B. de Jesus, Arturo} S. Gomez-Insuasti, Astrid R. Rivera, Juliana D. Messana, Roberta C. Canesin \& Telma T. Berchielli

To cite this article: Yury T. Granja-Salcedo, Carlos S. Ribeiro Júnior, Raphael B. de Jesus, Arturo S. Gomez-Insuasti, Astrid R. Rivera, Juliana D. Messana, Roberta C. Canesin \& Telma T. Berchielli (2016) Effect of different levels of concentrate on ruminal microorganisms and rumen fermentation in Nellore steers, Archives of Animal Nutrition, 70:1, 17-32, DOI: 10.1080/1745039X.2015.1117562

To link to this article: http://dx.doi.org/10.1080/1745039X.2015.1117562

\section{Published online: 11 Dec 2015.}

Submit your article to this journal 2

Џ Article views: 2

Q View related articles $\longleftarrow$

View Crossmark data \lceil 


\title{
Effect of different levels of concentrate on ruminal microorganisms and rumen fermentation in Nellore steers
}

\author{
Yury T. Granja-Salcedo ${ }^{a}$, Carlos S. Ribeiro Júniora, Raphael B. de Jesus ${ }^{a}$, \\ Arturo S. Gomez-Insuastia , Astrid R. Riverab ${ }^{b}$, Juliana D. Messana ${ }^{a}$, Roberta C. Canesinc \\ and Telma T. Berchiellia,d \\ aniversidad Estadual Paulista, Faculdade de Ciências Agrárias e Veterinárias, Departamento de Zootecnia, \\ São Paulo, Brazil; bUniversidad Nacional de Colombia sede Medellin, Facultad de Ciencias Agropecuarias, \\ Medellin, Colombia; 'Instituto de Zootecnia, Centro de Pesquisas em Pecuária de Corte, Sertãozinho, Brazil; \\ ${ }^{\mathrm{d} M e m b r o}$ INCT/CA - UFV - Departamento de Zootecnia, Viçosa, Brazil
}

\begin{abstract}
The aim of this study was to investigate the effect of different dietary levels of concentrate on feed intake, digestibility, ruminal fermentation and microbial population in steers. Eight Nellore steers fitted with ruminal cannulas were used in a double $4 \times 4$ Latin square design experiment. The dietary treatments consist of four different proportions of concentrate to roughage: 30:70, $40: 60,60: 40$ and $80: 20 \%$ in the dry matter, resulting in Diets 30, 40,60 and 80 , respectively. The roughage was corn silage, and the concentrate was composed of corn, soybean meal and urea. Apparent digestibility of organic matter and crude protein showed a linear association with concentrate proportion $(p=0.01)$, but the increased concentrate levels did not affect the digestibility of fibre. The lowest ruminal $\mathrm{pH}$-values were observed in animals fed with Diet 80 , remaining below $\mathrm{pH} 6.0$ from $6 \mathrm{~h}$ after feeding, while in the other diets, the ruminal $\mathrm{pH}$ was below 6.0 not before $12 \mathrm{~h}$ after feeding. After feeding Diet 80 , the ammonia concentration in the rumen was significantly the highest. Higher dietary concentrate levels resulted in a linear increase of propionic acid concentrations, a linear reduction of the ratio acetic acid to propionic acid $(p<0.01)$ and a linear increased synthesis of microbial nitrogen $(p<0.001)$. The predicted production of methane was lower in diets with greater amounts of concentrate $(p=0.032)$. The population of methanogens, $R$. flavefaciens and $R$. albus decreased with higher concentrate levels, while the population of $S$. ruminantium increased $(p<0.05)$. The results indicate that greater amounts of concentrate do not decrease ruminal $\mathrm{pH}$-values as much as expected and inhibit some cellulolytic bacteria without impairing the dry matter intake and fibre digestibility in Nellore steers.
\end{abstract}

\section{ARTICLE HISTORY}

Received 26 June 2015

Accepted 26 October 2015

\section{KEYWORDS}

Bacteria; digestibility; fibre content; protozoa; rumen fermentation; steers; volatile fatty acids

\section{Introduction}

Ruminal microorganisms transform plant forage into high-quality foods through microbial fermentation, which also produces enteric methane as a natural by-product (Murray et al. 1976). Therefore, rumen fermentation has been greatly manipulated by 
increasing the amount of concentrate in the diet, with the aim of satisfying nutritional requirements, improving animal productivity and reducing the environmental impact. However, the use of diets with a high amount of concentrate may be related with metabolic disorders related to the low $\mathrm{pH}$, high concentrations of volatile fatty acids (VFA) and high osmolality (Devries et al. 2014).

In addition, the grain-based concentrates may reduce the activity of fibrolytic microorganisms, which may cause a reduced digestibility, depressed nutrient intake and can lead to a decrease in the animal's performance (Archimède et al. 1997; González et al. 2012). However, in the rumen, the activity of consumers and producers of lactic acid increases because these microorganisms are not sensitive to lower $\mathrm{pH}$ and therefore can make use of greater substrate availability found in greater amounts of concentrates (Nagaraja and Titgemeyer 2007).

On the other hand, when ruminants fed with greater proportions of roughage this may limit the feed intake, reduces the energy efficiency and hence lesser the synthesis of microbial protein (Yang and Beauchemin 2006). Thereby, greater amounts of concentrate in the diet may improve the efficiency of microbial capture of ammonia in the rumen, thus bypassing the ammonia pool (Russell et al. 1983). Additionally, increasing the amount of concentrate in the diet has been used as a strategy to decrease methanogenesis per unit of feed intake, due to a shift in ruminal fermentation towards propionogenesis (Doreau et al. 2011).

In this study, the hypothesis was raised that greater amounts of concentrate in the diet can promote changes in the ruminal fermentation, resulting in a hostile environment for fibrolytic microorganisms, reducing the fibre breakdown and efficiency of use of the diets. The aim of this study was to investigate the effect of different dietary levels of concentrate on intake, digestibility, ruminal fermentation and microbial population in Nellore steers.

\section{Material and methods}

The protocol used in this study was in accordance with the Brazilian College of Animal Experimentation (COBEA - Colégio Brasileiro de Experimentação Animal) guidelines and was approved by the Ethics, Bioethics and Animal Welfare Committee (CEBEA Comissão de Ética e Bem Estar Animal) of the FCAV-UNESP-Jaboticabal campus, Brazil (protocol number 017621/11). The investigation was conducted at UNESP (Universidad Estadual Paulista), Faculdade de Ciências Agrárias e Veterinárias, Departamento de Zootecnia, Jaboticabal, São Paulo, Brazil.

\subsection{Animals and experimental diets}

Eight Nellore steers (initial body weight (BW) $308 \pm 10.4 \mathrm{~kg}$; final BW $389 \pm 13.2 \mathrm{~kg}$ ) fitted with silicone-type ruminal cannulas $(10 \mathrm{~cm}$ i.d.) and duodenal T-type cannulas were used in a double $4 \times 4$ Latin square design experiment. The diets were formulated to provide a dry matter intake (DMI) of $1.6 \%$ of BW and were calculated according to AFRC (1993). The roughage was corn silage and the concentrate was composed of corn, soybean meal and urea (Table 1). The dietary treatments consist of four different proportions of concentrate to roughage (corn silage): 30:70, 40:60, 60:40 and 80:20\% 
Table 1. Dietary ingredients and chemical composition.

\begin{tabular}{|c|c|c|c|c|}
\hline & \multicolumn{4}{|c|}{ Concentrate level of experimental diets } \\
\hline & $\begin{array}{c}30 \% \\
\text { (Diet 30) }\end{array}$ & $\begin{array}{c}40 \% \\
\text { (Diet 40) }\end{array}$ & $\begin{array}{c}60 \% \\
\text { (Diet 60) }\end{array}$ & $\begin{array}{c}80 \% \\
\text { (Diet } 80 \text { ) }\end{array}$ \\
\hline \multicolumn{5}{|l|}{ Ingredients [g/kg DM] } \\
\hline Corn silage & 700 & 600 & 400 & 200 \\
\hline Ground corn & 232 & 324 & 488 & 694 \\
\hline Soybean meal & 56 & 64 & 98 & 90 \\
\hline Urea & 12 & 12 & 14 & 16 \\
\hline \multicolumn{5}{|l|}{ Chemical composition } \\
\hline Dry matter (DM) $[\mathrm{g} / \mathrm{kg}]$ & 492 & 548 & 660 & 722 \\
\hline Organic matter $[\mathrm{g} / \mathrm{kg} \mathrm{DM}]$ & 942 & 943 & 943 & 941 \\
\hline Crude protein $(\mathrm{CP})[\mathrm{g} / \mathrm{kg} \mathrm{DM}]$ & 139 & 144 & 167 & 171 \\
\hline Ruminal degradable protein $[\% \mathrm{CP}]$ & 58.3 & 56.5 & 53.2 & 50.1 \\
\hline Ruminal non-degradable protein [\% CP] & 41.7 & 43.5 & 46.8 & 49.9 \\
\hline aNDFom $^{\dagger}[\mathrm{g} / \mathrm{kg} \mathrm{DM}]$ & 451 & 404 & 311 & 216 \\
\hline ADFom $^{\ddagger}[\mathrm{g} / \mathrm{kg} \mathrm{DM}]$ & 252 & 223 & 166 & 124 \\
\hline Hemicellulose $[\mathrm{g} / \mathrm{kg} \mathrm{DM}]$ & 211 & 194 & 159 & 116 \\
\hline Lignin $[\mathrm{g} / \mathrm{kg} \mathrm{DM}]$ & 28.2 & 25.3 & 19.3 & 13.5 \\
\hline Non-fibrous carbohydrates $[\mathrm{g} / \mathrm{kg} \mathrm{DM}]$ & 357 & 399 & 473 & 568 \\
\hline Total carbohydrates $[\mathrm{g} / \mathrm{kg} \mathrm{DM}]$ & 807 & 803 & 784 & 784 \\
\hline Starch $[\mathrm{g} / \mathrm{kg} \mathrm{DM}]$ & 266 & 291 & 331 & 388 \\
\hline Ether extract $[\mathrm{g} / \mathrm{kg} \mathrm{DM}]$ & 30.6 & 31.3 & 32.2 & 34.1 \\
\hline Gross energy $[\mathrm{MJ} / \mathrm{kg}]$ & 21.0 & 20.8 & 20.3 & 20.0 \\
\hline
\end{tabular}

in the dietary dry matter (DM), resulting in Diets 30, 40, 60 and 80, respectively. The ingredients of the concentrate were ground in a hammer mill fitted with strainers and $2 \mathrm{~mm}$ sieves. Continuous homogenisation of the diets was performed in a horizontal mixer for $15 \mathrm{~min}$.

For the feeding experiment, four consecutive $21-\mathrm{d}$ periods were used. Each study period consisted of $14 \mathrm{~d}$ for adaptation, $6 \mathrm{~d}$ for collection of faeces and urine, and $1 \mathrm{~d}$ for sampling ruminal fluid for measurement of ruminal $\mathrm{pH}$, ammonia $\mathrm{N}\left(\mathrm{NH}_{3}-\mathrm{N}\right)$ and VFA as well as bacteria and protozoa quantification.

Steers were kept in metabolism stalls equipped with individual feed bunks and water fountains during data collection. Animals were fed with corn silage, experimental concentrates and a mineral supplement (BELLNUTRI ${ }^{\infty}, 100 \mathrm{~g} / \mathrm{animal}$; contained per $\mathrm{kg}$ supplement: calcium, 146 g; phosphorus, $40 \mathrm{~g}$; sulphur, $40 \mathrm{~g}$; sodium, $130 \mathrm{~g}$; copper, $1.35 \mathrm{~g}$; manganese, $1.04 \mathrm{~g}$; zinc, $5 \mathrm{~g}$; iodine, $100 \mathrm{mg}$; cobalt, $80 \mathrm{mg}$; selenium, $26 \mathrm{mg}$; fluorine max. $800 \mathrm{mg}$ ). The feed was offered as a total mixed ration two times a day at 06:00 $\mathrm{h}$ and 16:00 $\mathrm{h}$.

Throughout the entire experimental period, the allowance was adjusted to allow refusals of approximately $100 \mathrm{~g} / \mathrm{kg}$ in relation to the total amount consumed on the previous day. Feed refusals were collected and weighed before feeding and subsamples were obtained and frozen at $-20^{\circ} \mathrm{C}$.

\subsection{Data collection and sampling procedures}

Total faeces were collected for $6 \mathrm{~d}$ to estimate the digestibility of nutrients. At the end of each collection day, faeces were weighed and homogenised. At the end of each 21-d study period, a composite sample was made for each animal based on the pre-dried 
weight of each sampling day. Total urine was collected for $6 \mathrm{~d}$ using funnel collectors attached to the animals. The funnel collector was connected to a polyethylene flexible tube, which directed the urine to containers containing $500 \mathrm{ml}$ of $\mathrm{H}_{2} \mathrm{SO}_{4}(200 \mathrm{ml} / \mathrm{l})$ to avoid loss of nitrogenous compounds. After each $24 \mathrm{~h}$ collection period, the total weight and volume of urine excreted were determined. Samples from the six sampling days were pooled and homogenised. A $10 \mathrm{ml}$ subsample was diluted with $40 \mathrm{ml}$ of $0.018 \mathrm{mM}$ $\mathrm{H}_{2} \mathrm{SO}_{4}$.

Ruminal contents were sampled on day 5 of each sampling period to determine the $\mathrm{pH}$ values and the concentrations of VFA and $\mathrm{NH}_{3}-\mathrm{N}$. Samples were taken at $0,2,4,6$, $8,10,12$ and $14 \mathrm{~h}$ after the morning feeding and $\mathrm{pH}$ was measured after the contents were filtered. Two aliquots of $20 \mathrm{ml}$ were stored at $-10^{\circ} \mathrm{C}$ and later used to determine $\mathrm{NH}_{3}-\mathrm{N}$ according to the methodology of Fenner (1965) adapted for use in Kjeldahl distillation, $2 \mathrm{ml}$ of sample were used with $10 \mathrm{ml}$ of distilled water and $5 \mathrm{ml}$ of $\mathrm{KOH} 2 \mathrm{~N}$; this mix was recovered in $20 \mathrm{ml}$ of boric acid to complete $50 \mathrm{ml}$ to titrate in hydrochloric acid $(0.05 \mathrm{~N})$. The VFA concentration was determined according to the methodology described by Palmquist and Conrad (1971).

Microbial protein synthesis was calculated via urinary total excretion of purine derivatives (allantoin + uric acid) according to the technique of Fujihara et al. (1987) described by Chen and Gomes (1992) and it was calculated according to Pina et al. (2009).

To measured organic matter (OM) apparently digested in the rumen (OMADR), duodenal samples were collected over $2 \mathrm{~d}$ (day 4 and 5 of sample collection during the study period) at 6-h intervals. Collection during the second sampling day was delayed to ensure that every $3 \mathrm{~h}$ in a 24 -h period was properly represented (Oliveira et al. 2007). Samples were kept at $-10^{\circ} \mathrm{C}$, and at the end of the period one sample was produced by pooling the samples for each animal in each period. Indigestible neutral detergent fibre (iNDF) was used as an indicator of daily DM flows in the duodenum (Harvatine and Allen 2006), obtained via an in situ methodology after $240 \mathrm{~h}$ (Casali et al. 2008) with incubated samples of feed offered, feed refusals, faeces and ground duodenal digesta (Wiley mill, $2 \mathrm{~mm}$ screen). The iNDF was analysed using an Ankom200 Fibre Analyser (Ankom Technology Fairport, NY, USA).

Feed offered, feed refusals and faeces samples were dried at $55^{\circ} \mathrm{C}$ for $72 \mathrm{~h}$ and ground in a Wiley mill (Thomas Scientific, Swedesboro, NJ, USA) to pass a $1 \mathrm{~mm}$ screen. Samples of corn silage, concentrates and feed refusals were analysed for DM (934.01), ash (942.05) and acid ether extract (954.02) according to AOAC (1990). The contents of ether extract were determined by extraction in ether (920.39). Nitrogen was determined using an LECO FP-528 nitrogen analyser (LECO Corp., St. Joseph, MI, USA). Gross energy was obtained by the combustion of samples in an adiabatic bomb calorimeter IKA model 2000 Basic.

Neutral detergent fibre (aNDFom) was determined using $\alpha$-amylase and without the addition of sodium sulphite following Van Soest et al. (1991) and adapted for the Ankom200 Fiber Analyzer. Acid detergent fibre (ADF) was determined using the method described by Goering and Van Soest (1970) and adapted for the Ankom200 Fiber Analyzer. Acid detergent lignin (lignin) was determined by solubilisation of cellulose with sulphuric acid according to Van Soest and Robertson (1985). Starch was determined enzymatically according to Bach Knudsen et al. (1987). 
Total carbohydrates and non-fibrous carbohydrates (NFC) were calculated values according to Sniffen et al. (1992). Ruminal degradable protein and ruminal nondegradable protein were calculated values according to Ørskov and McDonald (1979).

Measuring methane production in animals requires complex and often expensive equipment, and when cannulated cattle are used large animal numbers are needed to overcome the additional variability. Therefore, prediction equations are widely used to estimate methane emission. Some methane production was estimated by the equation of Ellis et al. (2007) derived from beef database models developed specifically to predict emissions. In this study, methane production $[\mathrm{MJ} / \mathrm{d}]$ was predicted from the metabolisable energy intake (MEI), ADF and lignin:

$$
\begin{aligned}
\mathrm{CH}_{4}[\mathrm{MJ} / \mathrm{d}]= & 2.94( \pm 1.16)+0.059( \pm 0.0201) \cdot \mathrm{MEI}[\mathrm{MJ} / \mathrm{d}]+1.44( \pm 0.331) \\
& \cdot \operatorname{ADF}[\mathrm{kg} / \mathrm{d}]-4.16( \pm 1.93) \text { Lignin }[\mathrm{kg} / \mathrm{d}]
\end{aligned}
$$

This equation was selected because the level of $\mathrm{CH}_{4}$ emissions caused by ruminal fermentation depends mainly on the composition and quantity of the diet (IPCC 1996), which was known in the present study. Furthermore, it has a low root mean square prediction error (RMSPE) (14.4\%) and the $R^{2}$ value for this equation was 0.85 . The $\mathrm{CH}_{4}$ energy was converted to a mass value using the conversion factor of $0.02 \mathrm{~kg} / \mathrm{MJ}$ (Brouwer 1965).

\subsection{Rumen bacteria and methanogens}

To determine the effect of diets on ruminal population, several ruminal bacteria were quantified by quantitative PCR. This included three bacteria species important for fibre degradation (Ruminococcus albus, Fibrobacter succinogenes and Ruminococcus flavefaciens), two ruminal bacteria important for starch digestion and lactic acid production (Streptococcus bovis and Selenomonas ruminantium) and rumen methanogens (Archaea).

Samples of ruminal contents were collected via cannula on day 16 of the trial period, before the morning feeding. Fifty grams of the rumen contents were weighed and

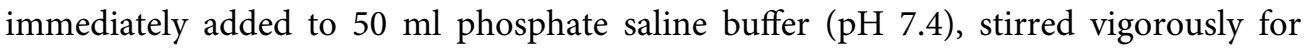
$3 \mathrm{~min}$ and then filtered with a mesh fabric (100 microns). The filtrate was subjected to centrifugation at $16,000 \mathrm{~g}$ for $10 \mathrm{~min}$ at $4^{\circ} \mathrm{C}$. The supernatant was discarded and the remaining precipitate was resuspended in $4 \mathrm{ml}$ of Tris-EDTA buffer (10X, $\mathrm{pH}$ 8.0). The resuspended content was centrifuged at $16,000 \mathrm{~g}$ for $10 \mathrm{~min}$ at $4^{\circ} \mathrm{C}$; the supernatant was discarded and the precipitate was immediately stored at $-20^{\circ} \mathrm{C}$ for a period of 2 months.

DNA extraction was conducted in samples of $250 \mathrm{mg}$ using the extraction kit AxyPrep $^{\mathrm{Tm}}$ Bacterial Genomic DNA Miniprep (Axygen-Biosciences). The integrity and quantity of the DNA were checked by electrophoresis on agarose gel $(0.8 \%)$, and complementary DNA was assessed by spectrophotometry (Thermo Scientific NanoDrop 1000) for evaluation of its quality and quantity.

For quantification of total bacteria and relative quantification of bacteria and methanogens, the technique used was relative qPCR. The primers used in this study are shown in Table 2. Four concentrations (200, 400, 600 and $800 \mathrm{nM}$ ) of forward and 
Table 2. PCR primers used in this study for the quantification of specific rumen microbes by $\mathrm{qPCR}$.

\begin{tabular}{|c|c|c|c|c|}
\hline & & Primers* $\left(5^{\prime}\right.$ to $\left.3^{\prime}\right)$ & Product size [bp] & Efficiency [\%] \\
\hline Total bacteria $^{\dagger}$ & $\begin{array}{l}\text { Forward } \\
\text { Reverse }\end{array}$ & $\begin{array}{l}\text { CGGCAACGACAACCC } \\
\text { CCATTGTAGCACCTGTGTAGCC }\end{array}$ & 130 & 100 \\
\hline Fibrobacter succinogenes ${ }^{\dagger}$ & $\begin{array}{l}\text { Forward } \\
\text { Reverse }\end{array}$ & $\begin{array}{l}\text { GTTCGGAATTACTGGGCGTAAA } \\
\text { CGCCTGCCCCTGAACTATC }\end{array}$ & 121 & 98 \\
\hline Ruminococcus flavefaciens $^{\dagger}$ & $\begin{array}{l}\text { Forward } \\
\text { Reverse }\end{array}$ & $\begin{array}{l}\text { CGAACGGAGATAATTTGAGTTTACTTAGG } \\
\text { CGGTCTCTGTATGTTATGAGGTATTACC }\end{array}$ & 132 & 96 \\
\hline Ruminococcus albus ${ }^{\ddagger}$ & $\begin{array}{l}\text { Forward } \\
\text { Reverse }\end{array}$ & $\begin{array}{l}\text { CCCTAAAAGCAGTCTTAGTTCG } \\
\text { CCTCCTTGCGGTTAGAACA }\end{array}$ & 175 & 96 \\
\hline Streptococcus bovis ${ }^{\S}$ & $\begin{array}{l}\text { Forward } \\
\text { Reverse }\end{array}$ & $\begin{array}{l}\text { TTCCTAGAGATAGGAAGTTTCTTCGG } \\
\text { ATGATGGCAACTAACAATAGGGGT }\end{array}$ & 127 & 95 \\
\hline Selenomonas ruminantium ${ }^{\S}$ & $\begin{array}{l}\text { Forward } \\
\text { Reverse }\end{array}$ & $\begin{array}{l}\text { GGCGGGAAGGCAAGTCAGTC } \\
\text { CCTCTCCTGCACTCAAGAAAGACAG }\end{array}$ & 83 & 98 \\
\hline Methanogens ${ }^{\star}$ & $\begin{array}{l}\text { Forward } \\
\text { Reverse }\end{array}$ & $\begin{array}{l}\text { TTCGGTGGATCDCARAGRGC } \\
\text { GBARGTCGWAWCCGTAGAATCC }\end{array}$ & 140 & 95 \\
\hline
\end{tabular}

Notes: *Primers used for qPCR normalisation; ${ }^{\dagger}$ Denman and McSweeney (2006); ${ }^{\ddagger}$ Koike and Kobayash (2001); ${ }^{5}$ Khafipour et al. (2009); "Denman et al. (2007).

reverse primers were tested to determine minimum primer concentration giving the lowest threshold cycle $\left(C_{t}\right)$ and to reduce non-specific amplification before starting the reaction.

The amplifications were performed in triplicate and negative controls were run in the assay, omitting the total DNA. Real-time PCR was performed with Applied Biosystems 7500 Real-time PCR System (Applied Biosystems). Rox was used as a passive reference dye. The qPCR reaction was carried out using $100 \mathrm{ng}$ of total DNA in a reaction containing 6.25 $\mu \mathrm{l}$ of SYBR Green PCR Master Mix (Bio-Rad, Hercules, CA, USA), 400 or $600 \mathrm{nM}$ of primer pair and $\mathrm{H}_{2} \mathrm{O}$ to a final volume of $12.5 \mu \mathrm{l}$. Cycling conditions were $50^{\circ} \mathrm{C}$ for $2 \mathrm{~min}, 95^{\circ} \mathrm{C}$ for $10 \mathrm{~min}$ and 35 cycles with denaturation $95^{\circ} \mathrm{C}$ for $15 \mathrm{~s}$, pairing $60^{\circ} \mathrm{C}$ for $60 \mathrm{~s}$ and extension $78^{\circ} \mathrm{C}$ for $1 \mathrm{~min}$. After one cycle of amplification, a step was added to increase the temperature from $60^{\circ} \mathrm{C}$ to $95^{\circ} \mathrm{C}$ to obtain a dissociation curve of the reaction products, used for analysing the specificity of amplification.

Relative quantification was used to determine species proportion. The results were expressed as a $16 \mathrm{~S}$ rDNA ratio of general bacteria, following the equation:

$$
\text { Relative quantification }=2^{-\left[C_{t} \text { target }-C_{t} \text { total bacteria }\right]}
$$

where $C_{\mathrm{t}}$ is defined as the number of cycles required for the fluorescent signal to cross the threshold.

\subsection{Rumen ciliate protozoa}

For the quantification and identification of rumen ciliate protozoa, samples of ruminal contents were collected via cannula on day 16 of the trial period after $3 \mathrm{~h}$ of morning feeding. Cell counts were obtained from rumen content aliquots that were preserved in formalin (a solution of equal parts water and $370 \mathrm{ml}$ formaldehyde per 1) according to D'Agosto and Carneiro (1999). Direct counts of protozoa were performed in a Sedgewick-Rafter counting chamber (Dehority 1984). The samples were diluted with $200 \mathrm{ml}$ glycerol per 1 and stained using Lugol's solution before counting the cells 
(D’Agosto and Carneiro 1999). Cell counts were obtained from rumen content aliquots that were preserved in formalin (a solution of equal parts water and $370 \mathrm{ml}$ formaldehyde per l) (D’Agosto and Carneiro 1999).

\subsection{Statistical analyses}

Feed intake, digestibility, microbial protein synthesis, methane predicted and protozoa quantification data were analysed as a double $4 \times 4$ Latin square using the Proc MiXeD procedure of Statistical Analysis System software version 9.02 (SAS Institute, Cary, NC, USA). The fixed effect of the model consisted of the diet and random effects consisted of animals and periods.

The general mathematical model was represented as follows:

$$
Y_{i j k}=\mu+\alpha_{i}+\beta_{j}+s_{k}+\alpha \beta_{i j}+e_{i j k}
$$

in which $Y_{i j k}$ represents the observation on steers $k$ receiving diet $i$ at period $j ; \alpha_{i}$ represents the fixed effect of the $i$-th diet, $i=1,2, \ldots, n t ; \beta_{j}$ represents the fixed effect of the $j$-th period, $j=1,2, \ldots, n p$ and $s_{k}$ represents the random effect of the $k$-th steers, $k=1,2, \ldots, n c$, with variance component $\sigma_{c}^{2}$. Ruminal $\mathrm{pH}, \mathrm{NH}_{3}-\mathrm{N}$ and VFA data were analysed as double $4 \times 4$ Latin square data with repeated ANOVA. The model included fixed effects of diet, time and the interaction. Random effects consisted of steers and periods. When the results of ANOVA were significant, for the analyses of feed intake, digestibility, protozoa population, $\mathrm{pH}, \mathrm{NH}_{3}-\mathrm{N}$ and VFA Tukey's test was carried out for comparison between treatments, time or the interaction diet $\times$ time, and the effects of diet were tested for linear or quadratic effects. Differences among means with $p<0.05$ were considered as statistically significant differences.

Relative quantities of $16 \mathrm{~S}$ rRNA as determined from real-time PCR were analysed using PROC ANOM to determine significant differences in copy number between treatments for each targeted bacterial species. The significance levels of $p<0.05$ were accepted statistically significant differences.

\section{Results}

\subsection{Intake, digestibility and rumen fermentation}

The intake of crude protein (CP) showed a quadratic association with concentrate levels (Table 3; $p=0.01$ ), where the lowest values were observed for animals fed Diet $40(p=0.002)$. Increasing the level of dietary concentrates resulted in a linear decreased intake of aNDFom $(p<0.05)$ and linear increased intake of NFC $(p=0.040)$.

However, the different proportions of concentrate did not affect digestibility of aNDFom. In all diets, aNDFom intake was below $1.2 \%$ of BW. Diet 30 showed the lowest apparent digestibility of DM, OM and CP. Apparent digestibility of OM and CP showed a linear association with the concentrate proportion $(p=0.01)$.

The lowest ruminal $\mathrm{pH}$ was observed in animals fed Diet 80 , where the $\mathrm{pH}$ remained below 6.0 from $6 \mathrm{~h}$ after feeding until the end of measurements at $14 \mathrm{~h}$ after feeding. All 
Table 3. Effect of different dietary levels of concentrate on intake and digestibility in Nellore steers.

\begin{tabular}{|c|c|c|c|c|c|c|c|}
\hline & \multicolumn{4}{|c|}{ Concentrate level of experimental diets } & \multirow[b]{2}{*}{ SEM $^{*}$} & \multicolumn{2}{|c|}{$p$-Values ${ }^{\ddagger}$} \\
\hline & $\begin{array}{c}30 \% \\
\text { (Diet 30) }\end{array}$ & $\begin{array}{c}40 \% \\
\text { (Diet } 40)\end{array}$ & $\begin{array}{c}60 \% \\
\text { (Diet 60) }\end{array}$ & $\begin{array}{c}80 \% \\
\text { (Diet } 80 \text { ) }\end{array}$ & & $\begin{array}{l}\text { Linear } \\
\text { contrasts }\end{array}$ & $\begin{array}{l}\text { Quadratic } \\
\text { contrasts }\end{array}$ \\
\hline \multicolumn{8}{|l|}{ Intake $[\mathrm{kg} / \mathrm{d}]$} \\
\hline Dry matter & 5.63 & 5.32 & 6.05 & 5.77 & 0.421 & $-\#$ & - \\
\hline Organic matter & 5.14 & 4.75 & 5.77 & 4.37 & 0.462 & - & - \\
\hline Crude protein & $0.82^{\mathrm{ab}}$ & $0.79^{\mathrm{b}}$ & $0.99^{a}$ & $0.96^{\mathrm{ab}}$ & 0.078 & - & $<0.01$ \\
\hline Ether extract & 0.20 & 0.18 & 0.22 & 0.20 & 0.014 & - & - \\
\hline aNDFom $^{\dagger}$ & $2.40^{\mathrm{a}}$ & $2.05^{\mathrm{b}}$ & $1.89^{\mathrm{b}}$ & $1.40^{\mathrm{C}}$ & 0.159 & $<0.01$ & - \\
\hline Non-fibrous carbohydrates & $2.64^{\mathrm{b}}$ & $2.59^{b}$ & $3.43^{\mathrm{a}}$ & $3.35^{\mathrm{a}}$ & 0.537 & $<0.01$ & - \\
\hline \multicolumn{8}{|c|}{ Coefficients of total apparent digestibility } \\
\hline Dry matter & $0.70^{\mathrm{b}}$ & $0.77^{\mathrm{a}}$ & $0.80^{\mathrm{a}}$ & $0.76^{\mathrm{a}}$ & 0.016 & - & $<0.01$ \\
\hline Organic matter & $0.69^{\mathrm{b}}$ & $0.78^{\mathrm{a}}$ & $0.77^{\mathrm{a}}$ & $0.77^{\mathrm{a}}$ & 0.014 & $<0.01$ & - \\
\hline Crude protein & $0.61^{c}$ & $0.70^{\mathrm{b}}$ & $0.74^{\mathrm{ab}}$ & $0.80^{\mathrm{a}}$ & 0.028 & $<0.01$ & - \\
\hline aNDFom & 0.66 & 0.63 & 0.63 & 0.64 & 0.022 & - & - \\
\hline Gross energy & 0.84 & 0.82 & 0.86 & 0.85 & 0.029 & - & - \\
\hline
\end{tabular}

Notes: ${ }^{*}$ SEM, standard error of the mean; ${ }^{\ddagger} p$-Values for non-significant contrasts $(p>0.05)$ are not reported; ${ }^{\dagger}$ aNDFom, neutral detergent fibre assayed with a heat stable amylase and expressed exclusive of residual ash; ${ }^{-}$, not significant; ${ }^{\mathrm{a}, \mathrm{b}}$ Means not sharing the same superscript are significantly different at $p<0.05$.

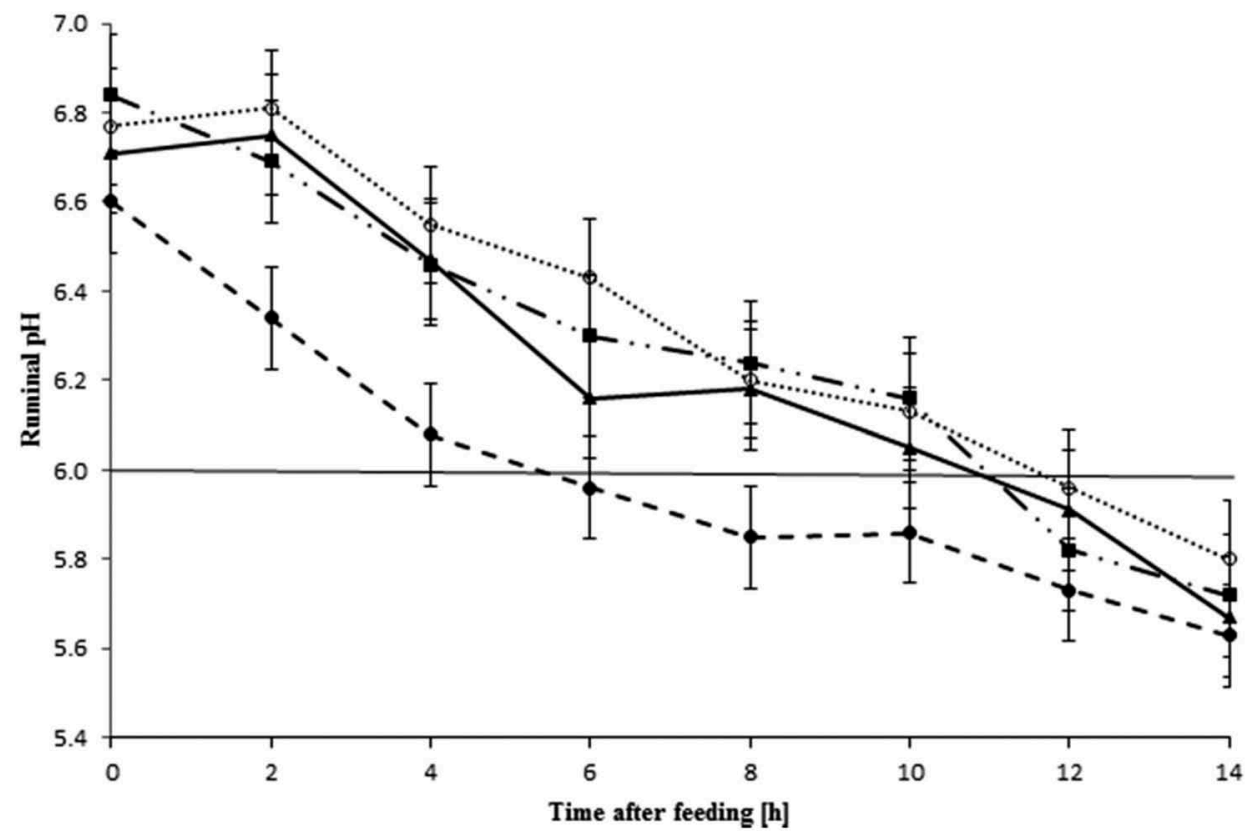

Figure 1. Ruminal $\mathrm{pH}$ in Nellore steers fed diets with different proportions of concentrate in the dietary dry matter: $30 \%(0) ; 40 \%(\boldsymbol{\Delta}) ; 60 \%(\boldsymbol{\bullet})$ or $80 \%(\bullet)$. The critical point of ruminal pH for cellulolytic bacteria at pH 6.0 according to Russell and Dombrowski (1980) is indicated by a horizontal line. After the first feeding at $0 \mathrm{~h}$, steers were fed again after $10 \mathrm{~h}$. Error bars are standard errors of the mean.

other diets caused a $\mathrm{pH}$-value $>6.0$ until $10 \mathrm{~h}$ after feeding (Figure 1). The ruminal $\mathrm{N}-\mathrm{NH}_{3}$ concentration after feeding Diet 80 was the highest and differed significantly from all other groups (Table 4). 
Table 4. Effect of different dietary levels of concentrate on rumen fermentation parameters, efficiency of microbial synthesis and predicted enteric methane in Nellore steers.

\begin{tabular}{|c|c|c|c|c|c|c|c|}
\hline & \multicolumn{4}{|c|}{ Concentrate level of experimental diets } & \multirow[b]{2}{*}{$\mathrm{SEM}^{*}$} & \multicolumn{2}{|c|}{$p$-Values ${ }^{\diamond}$} \\
\hline & $\begin{array}{c}30 \% \\
\text { (Diet 30) }\end{array}$ & $\begin{array}{c}40 \% \\
\text { (Diet } 40)\end{array}$ & $\begin{array}{c}60 \% \\
\text { (Diet 60) }\end{array}$ & $\begin{array}{c}80 \% \\
\text { (Diet } 80)\end{array}$ & & Diet & Time \\
\hline $\mathrm{pH}$ & $6.33^{\mathrm{a}}$ & $6.23^{\mathrm{a}}$ & $6.27^{\mathrm{a}}$ & $6.00^{\mathrm{b}}$ & 0.041 & $<0.01\left(\mathrm{~L}^{\dagger}\right)$ & $<0.01(\mathrm{~L})$ \\
\hline $\mathrm{N}-\mathrm{NH}_{3}[\mathrm{mg} / \mathrm{dl}]$ & $22.9^{\mathrm{b}}$ & $21.1^{\mathrm{bc}}$ & $18.4^{\mathrm{C}}$ & $30.9^{\mathrm{a}}$ & 3.82 & $<0.01\left(Q^{\ddagger}\right)$ & ${ }^{\#}$ \\
\hline \multicolumn{8}{|c|}{ Volatile fatty acids (VFA) [mmol/l] } \\
\hline Total VFA & 98.7 & 101.0 & 96.8 & 105.0 & 4.89 & - & - \\
\hline Acetic acid (C2) & 67.5 & 68.3 & 64.6 & 64.9 & 3.59 & - & - \\
\hline Propionic acid (C3) & $16.1^{\mathrm{b}}$ & $17.2^{\mathrm{b}}$ & $18.1^{\mathrm{b}}$ & $23.6^{\mathrm{a}}$ & 2.30 & $<0.01(\mathrm{~L})$ & - \\
\hline iso-butyric acid (C4) & 0.93 & 0.95 & 0.97 & 1.01 & 0.052 & - & - \\
\hline Butyric acid (C4) & $9.93^{\mathrm{ab}}$ & $11.0^{\mathrm{a}}$ & $9.07^{\mathrm{b}}$ & $11.7^{\mathrm{a}}$ & 1.10 & $<0.01(\mathrm{Q})$ & $<0.01(Q)$ \\
\hline iso-valeric acid (C5) & 2.89 & 3.40 & 3.03 & 3.09 & 0.221 & - & - \\
\hline Valeric acid (C5) & 1.79 & 1.49 & 1.46 & 1.63 & 0.239 & - & - \\
\hline $\mathrm{C} 2: \mathrm{C} 3$ & 4.26 & 4.16 & 3.82 & 3.61 & 0.683 & $<0.01(\mathrm{~L})$ & - \\
\hline Microbial $N[\mathrm{~g} / \mathrm{d}]$ & $56.2^{c}$ & $71.8^{\mathrm{b}}$ & $71.2^{\mathrm{b}}$ & $85.9^{\mathrm{a}}$ & 3.21 & $<0.01(\mathrm{~L})$ & - \\
\hline $\begin{array}{l}\text { Efficiency of microbial synthesis } \\
\left.\text { [g microbial N/kg OMADR }{ }^{\dagger}\right]\end{array}$ & 12.4 & 13.9 & 12.4 & 14.2 & 1.74 & - & - \\
\hline $\begin{array}{l}\text { Predicted enteric methane } \\
\qquad\left[\mathrm{g} \mathrm{CH}_{4} / \mathrm{kg} \mathrm{OMADR}\right]\end{array}$ & $57.0^{\mathrm{a}}$ & $56.1^{\mathrm{a}}$ & $55.1^{\mathrm{a}}$ & $49.5^{b}$ & 0.01 & $<0.05(\mathrm{~L})$ & - \\
\hline
\end{tabular}

Notes: ${ }^{*}$ SEM, standard error of the mean; ${ }^{\circ} p$-Values for non-significant contrasts $(p>0.05)$ are not reported; ${ }^{\dagger} L$, linear contrast; ${ }^{\ddagger} Q$, quadratic contrast; ${ }^{\#}$-, not significant; ${ }^{\dagger}$ OMADR, organic matter apparently digested in the rumen; ${ }^{\mathrm{a}, \mathrm{b}}$ Means not sharing the same superscripts are significantly different at $p<0.05$.

The concentration of total rumen VFA, acetic acid, iso-valeric acid and valeric acid was not influenced by experimental feeding (Table 4). However, increasing proportions of concentrate in the diet resulted in a linear increased concentration of propionic acid and linear reduction of the ratio acetic acid: propionic acid (C2:C3) $(p<0.01)$.

With increasing amounts of concentrate, a linear increased synthesis of microbial nitrogen was observed (Table $4, p<0.001$ ). However, the efficiency of microbial synthesis did not differ among treatments. The predicted methane production showed a linear decrease with increasing the proportion of concentrate in the diet $(p=0.032)$.

\subsection{Changes in ruminal microorganism}

The profile of ruminal microbiota changes according to different diet compositions. Different proportions of concentrate can alter the rumen microbial population. In order to assess the treatment effect on the microbial population, the rumen microorganisms of animals fed Diets 30 and 80 were quantified. With increasing amounts of concentrate in the diet, the relative proportion of $R$. flavefaciens and $R$. albus decreased by 9 and 12 times, respectively $(p<0.05)$, but no difference was observed in the population of $F$. succinogenes (Table 5). Feeding Diet 80 was associated with an increased proportion of $S$. ruminantium (2 times, $p=0.025$ ), while for $S$. bovis the numerical increase was not significant (Table 5). The proportion of methanogens decreased two times with increasing amounts of concentrate in the diet $(p<0.05)$.

The total number of protozoa was similar after feeding different proportions of concentrate (Table 6). Independent of the experimental diet, the genus Entodinium was most frequent in the rumen, representing $99.3 \%$ of all protozoa. The greatest diversity of genera of protozoa was observed in Diet 40, where nine genera were identified. The presence of the genera Metadinium and Elytroplastron was observed in 
Table 5. Effect of different dietary levels of concentrate on ruminal bacteria and methanogens population of Nellore steers. ${ }^{\dagger}$

\begin{tabular}{lcccc}
\hline & \multicolumn{2}{c}{ Concentrate level of experimental diets } & & \\
\cline { 2 - 4 } & $\begin{array}{c}30 \% \\
\text { (Diet 30) }\end{array}$ & $\begin{array}{c}80 \% \\
\text { (Diet 80) }\end{array}$ & SEM* & $p$-Value \\
\hline Fibrobacter succinogenes & 0.008 & 0.007 & 0.002 & 0.545 \\
Ruminococcus flavefaciens & $0.134^{\mathrm{a}}$ & $0.015^{\mathrm{b}}$ & 0.057 & 0.049 \\
Ruminococcus albus & $0.561^{\mathrm{a}}$ & $0.045^{\mathrm{b}}$ & 0.192 & 0.028 \\
Selenomonas ruminantium & $0.030^{\mathrm{b}}$ & $0.079^{\mathrm{a}}$ & 0.037 & 0.025 \\
Streptococcus bovis & 0.001 & 0.003 & 0.001 & 0.066 \\
Methanogens & $1.092^{\mathrm{a}}$ & $0.581^{\mathrm{b}}$ & 0.445 & 0.014 \\
\hline
\end{tabular}

Notes: ${ }^{\dagger}$ Microbes measured as a proportion of total estimated rumen bacterial 16S ribosomal RNA gene (relative quantification $=2^{-(\mathrm{Ct} \text { target-Ct total bacteria) })}$; ${ }^{*} \mathrm{SEM}$, standard error of the mean; ${ }^{\mathrm{a}, \mathrm{b}}$ Means with different superscripts are differ significantly at $p<0.05$.

Table 6. Effect of different dietary levels of concentrate on the population of rumen protozoa in Nellore steers.

\begin{tabular}{|c|c|c|c|c|c|c|}
\hline \multirow[b]{2}{*}{ Protozoa } & \multicolumn{4}{|c|}{ Concentrate level of experimental diets } & \multirow[b]{2}{*}{ SEM* } & \multirow[b]{2}{*}{$\begin{array}{c}p \text {-Values } \\
\text { (Diet effect) }\end{array}$} \\
\hline & $\begin{array}{c}30 \% \\
\text { (Diet 30) }\end{array}$ & $\begin{array}{c}40 \% \\
\text { (Diet 40) }\end{array}$ & $\begin{array}{c}60 \% \\
\text { (Diet 60) }\end{array}$ & $\begin{array}{c}80 \% \\
\text { (Diet } 80 \text { ) }\end{array}$ & & \\
\hline Total protozoa $\left[\mathrm{n} \cdot 10^{6} / \mathrm{ml}\right]$ & 2.31 & 1.69 & 2.11 & 2.14 & 0.128 & $-\#$ \\
\hline Entodinium $\left[\mathrm{n} \cdot 10^{6} / \mathrm{ml}\right]$ & 2.30 & 1.66 & 2.11 & 2.13 & 0.109 & - \\
\hline Eudiplodinium $\left[\mathrm{n} \cdot 10^{4} / \mathrm{ml}\right]$ & $0.28^{\mathrm{b}}$ & $0.64^{\mathrm{a}}$ & $0.04^{c}$ & $0.08^{\mathrm{C}}$ & 0.091 & $<0.01\left(\mathrm{~L}^{\dagger}\right)$ \\
\hline Metadinium $\left[\mathrm{n} \cdot 10^{4} / \mathrm{ml}\right]$ & $0.44^{\mathrm{a}}$ & $0.20^{\mathrm{a}}$ & $0.00^{\mathrm{b}}$ & $0.00^{\mathrm{b}}$ & 0.003 & $<0.01(\mathrm{~L})$ \\
\hline Eremoplastron $\left[\mathrm{n} \cdot 10^{4} / \mathrm{ml}\right]$ & $0.00^{c}$ & $1.84^{\mathrm{a}}$ & $0.08^{\mathrm{b}}$ & $0.16^{\mathrm{b}}$ & 0.108 & $<0.01\left(\mathrm{Q}^{\ddagger}\right)$ \\
\hline Diploplastron $\left[\mathrm{n} \cdot 10^{4} / \mathrm{ml}\right]$ & $0.00^{c}$ & $0.88^{\mathrm{a}}$ & $0.32^{\mathrm{b}}$ & $0.00^{c}$ & 0.002 & $<0.01(\mathrm{Q})$ \\
\hline Elytroplastron $\left[\mathrm{n} \cdot 10^{4} / \mathrm{ml}\right]$ & $0.04^{\mathrm{b}}$ & $0.16^{\mathrm{a}}$ & $0.00^{c}$ & $0.00^{c}$ & 0.001 & $<0.01(\mathrm{Q})$ \\
\hline Polyplastron $\left[\mathrm{n} \cdot 10^{4} / \mathrm{ml}\right]$ & $0.00^{\mathrm{b}}$ & $0.02^{\mathrm{a}}$ & $0.00^{\mathrm{b}}$ & $0.00^{\mathrm{b}}$ & 0.001 & $<0.01(\mathrm{Q})$ \\
\hline Isotricha $\left[\mathrm{n} \cdot 10^{4} / \mathrm{ml}\right]$ & $0.00^{\mathrm{b}}$ & $0.04^{a}$ & $0.00^{\mathrm{b}}$ & $0.00^{\mathrm{b}}$ & 0.002 & $<0.01(\mathrm{Q})$ \\
\hline
\end{tabular}

Notes: ${ }^{*}$ SEM, standard error of the means; ${ }^{\#-}$, not significant; ${ }^{\dagger} \mathrm{L}$, linear contrast; ${ }^{\ddagger} \mathrm{Q}$, quadratic contrast; ${ }^{\mathrm{a}, \mathrm{b}}$ Means with different superscripts are significantly different at $p<0.05$.

diets with lower proportions of concentrate (Diets 30 and 40); whereas the genera Eremoplastron and Diploplastron were observed in diets with medium and higher amounts of concentrate (Table 6).

\section{Discussion}

In this study, the effect of different dietary concentrate levels on microbial population and ruminal fermentation in Nellore steers were evaluated. It was found that greater amounts of concentrate altered some rumen microorganisms, however, did not affect fibre digestibility. Thus, the hypothesis that higher proportions of concentrate in the diet of Nellore steers may result in a hostile environment for fibrolytic rumen microorganisms reducing the fibre breakdown and the feed efficiency was not supported.

\subsection{Intake, digestibility and rumen fermentation}

It was expected that a higher dietary NDF concentration due to lower proportions of concentrate decreases the DMI of Nellore steers, due to distension in the gastrointestinal tract, which can limit the voluntary DMI in ruminants (Forbes 1996). However, in 
this study diets with enlarged roughage level did not affect DMI; thus, bulk fill was not a limiting factor.

On the other hand, when forage is preserved as silage, the accumulation of fermentation end products can further limit feed intake (Huhtanen et al. 2007). Additionally, the intake is also associated with energy balance during longer periods of time and is related to the metabolic status of the animal (Carter and Grovum 1990). An increased amount of fermentable carbohydrate in the diet results in a higher fermentation rate, providing the animal with more energy for growth (Nagaraja and Titgemeyer 2007). The present results suggest that the lack of treatment effect on DMI results from the fact that the changes on VFA concentration were not sufficient to activate the satiety centre of the hypothalamus (Allen 2000). This is in line with previous investigations showing similar results for Nellore steers, which received the same increasing concentrate proportions (Ribeiro et al. 2015).

In this study, it was found that after feeding Diet 80 , the ruminal $\mathrm{pH}$ was below 6.0 for a longer period. This was due to a higher NFC intake and the large amount of corn in that diet, which affects some microorganism in the rumen. The replacement of roughage by concentrate can reduce the mean particle size in the diet, increase the rate of degradation and usually results in a greater VFA production and molar proportion of propionate while reducing ruminal $\mathrm{pH}$ (Yang and Beauchemin 2006). Our results are consistent with other studies showing that higher proportions of NFC with lesser aNDFom in the diet of ruminants have been caused a low ruminal $\mathrm{pH}$ (Blanch et al. 2009).

Furthermore, it was observed that replacing roughage with concentrate increased the CP intake in Diet 80, an effect that can be explained by the higher CP content in this diet. The highest ruminal $\mathrm{N}-\mathrm{NH}_{3}$ concentration found in Diet 80 may be due to a greater level of urea in this diet and the highly digestible nature of its ingredients. In all diets tested, the $\mathrm{N}-\mathrm{NH}_{3}$ concentration remained above the optimal level $(10 \mathrm{mg} / \mathrm{dl})$ recommended and required for microbial growth in the rumen (Satter and Roffler 1975).

The similarity in the production of microbial $\mathrm{N}$ in Diets 40 and 60 is a reflection of similar intake and digestibility of nutrients and similar values of $\mathrm{pH}, \mathrm{VFA}$ and $\mathrm{NH}_{3}-\mathrm{N}$ in these diets, providing comparable substrates, rumen environment and fermentation characteristics that resulted in similar microbial growth. The further increased availability of NFC with greater amounts of concentrate optimised the synthesis of microbial cells, which was reflected in an extended synthesis of microbial $\mathrm{N}$ in Diet 80 .

In the present study, an effect of different concentrate levels on the efficiency of microbial synthesis was not observed. It should be noted that besides the proportion of nutrients in the diet and greater sources of readily fermentable carbohydrates, other factors have been associated with the efficiency of microbial synthesis, such as the synchronisation of the degradation of foods that make up the diet and greater supply of ruminal degradable protein (Calsamiglia et al. 2010).

\subsection{Changes in ruminal microorganism}

Changes in the diet, such as the amount of fibre or starch, can affect the supply of substrates as well the microbial growth (González et al. 2012). The fact that after feeding Diet 80 the ruminal microorganisms remained for longer periods in an environment 
with low $\mathrm{pH}$ (Figure 1) was the main factor responsible for decreasing the relative proportion of cellulolytic bacteria $R$. albus and $R$. flavefaciens. Our results are consistent with observations made earlier by Russell and Dombrowski (1980), reporting a high sensitivity of microorganisms to low $\mathrm{pH}$ when values remain below 6.0 , which results in reduced activity.

Studies of Russell and Dombrowski (1980) and Fernando et al. (2010) indicated that F. succinogenes is highly sensitive to an acidic ruminal environment. However, this sensitivity was not observed in our study. Although the ruminal microorganisms remained for longer periods at lower $\mathrm{pH}$ after feeding Diet 80, the proportion of $F$. succinogenes did not change. Probably, this result can be attributed to the fact that $F$. succinogenes are gram-negative bacteria and have different cell membranes than $R$. albus and $R$. flavefaciens. In addition, some studies reported a tendency to increase the ruminal population of Fibrobacter spp. when animals were fed with silage (Ramirez et al. 2012).

Interestingly, compared with other fibrolytic species, such as Ruminococcus spp., F. succinogenes digest fibre faster and to a greater extent and even digests crystalline cellulose more actively (Kobayashi et al. 2008). The unique fibrolytic capacity of $F$. succinogenes probably explains why the fibre digestibility was not affected in our study.

However, recent studies showed that the fibre digestibility was reduced to a larger extent when the proportions of concentrate in the diet were increased (Ribeiro et al. 2015), especially when grain-based concentrates were fed (Archimède et al. 1997). It has to be emphasised that even though $R$. albus, R. flavefaciens and F. succinogenes are the most important microbes in ruminal fibre degradation, there are other bacterial populations not evaluated in this study, which are involved in the digestibility of the fibre. Additionally, a depression of fibre degradation in the rumen is balanced by an increased degradation in the hindgut (Metzler-Zebeli et al. 2013), and parameters other than these analysed here, such as the rate of passage and intake, also play a role in fibre digestibility.

Ruminal $\mathrm{pH}$ is a critical factor in the maintenance of ciliated protozoa in the rumen (Franzolin and Dehority 2010). However, after feeding Diet 80, the total number of protozoa was not changed, even longer periods at lower $\mathrm{pH}$. The genus Entodinium is the group of ruminal protozoa most resistant to low $\mathrm{pH}$ and it is the most dominant fraction, accounting for $90-99 \%$ of the total population in cattle fed high-grain diets (Nagaraja and Lechtenberg 2007). This explains why the total number of protozoa in our study did not change after feeding different proportions of concentrate.

In Diets 60 and 80, lower concentrations of Eudiplodinium protozoa were found, which is most likely due to the lower aNDFom intake in case of these diets. The preference of this genus for swallowing cellulose particles and using this substrate in their metabolism (Naga and El-Shazly 1968) may have limited the activity of these microorganisms.

The genus Diploplastron was observed in diets with medium to higher proportions of concentrate (Diets 40 and 60), which can be explained by the fact that this genus of protozoa has the particularity to participate as a fibrolyitic and amylolytic microorganism in ruminal fermentation (Wereszka and Michałowski 2012). 
The inclusion of concentrates into diets for ruminants is also a strategy to optimise the rumen environment and to reduce methane emissions by an increased propionogenesis (Doreau et al. 2011). In the present study, it was observed that an increased dietary concentrate level reduced the predicted enteric methane production and the population of methanogens. This might be explained by an increased propionogenesis observed for Diet 80, and because the propionate pathway acts as an $\mathrm{H}_{2}$ sink, it should decrease the available $\mathrm{H}_{2}$ to methanogens (Doreau et al. 2011).

Diets rich in NFC and with low fibre levels promote growth of amylolytic bacteria in the rumen. S. ruminantium is a species producing propionate through succinate decarboxylation (Stewart et al. 1997). This bacterium has the ability to utilise starch and sugars for growth. The highest concentration of propionic acid was found after feeding Diet 80 due to a higher concentration of starch in this diet. This is consistent with an increase in the relative proportion of S. ruminantium in the rumen. Similar to our results, the highest concentrations of propionic acid (Sutton et al. 2003) and increasing populations of S. ruminantium (Fernando et al. 2010) have been reported in the rumen of cattle fed high-grain diets. In addition, S. ruminantium has also the ability to utilise lactic acid, favouring the control of rumen $\mathrm{pH}$ (Russell and Baldwin 1978). Thus, the increase of its population in the rumen promoted an increasing use of fermentable substrates produced in the rumen after feeding Diet 80 .

$S$. bovis is a facultative anaerobe known to predominate during lactic acidosis in ruminants fed high amounts of concentrate (González et al. 2012). Activity of S. bovis only increases at $\mathrm{pH}$ values below 5.75 (Russell and Dombrowski 1980). In our study, $\mathrm{pH}$ values above 5.75 were observed for all diets most times after feeding. As in our study, other studies did not find significant differences in $S$. bovis in ruminants fed high amounts of dietary concentrates (Fernando et al. 2010). Additionally, because of the fast rate of NFC fermentation in the rumen, growth of $S$. bovis was not observed when steers were adapted to diets rich in NFC (Nagaraja and Titgemeyer 2007).

In summary, this study suggests that diets with greater inclusion rates of concentrate can inhibit the growth of some cellulolytic bacteria without impairing the DMI and fibre digestibility in Nellore steers. In addition, higher amounts of concentrate in the diet result in a reduction of enteric methane production and the rumen population of methanogens through increasing the propionogenesis, which can reduce energy losses and the environmental impact.

\section{Disclosure statement}

No potential conflict of interest was reported by the authors.

\section{Funding}

The authors would like to thank the São Paulo Research Foundation (FAPESP - Fundação de Amparo à Pesquisa do Estado de São Paulo) and the Conselho Nacional de Desenvolvimento Científico e Tecnológico (CNPq) for the financial support to conduct the research. 


\section{References}

[AFRC] Agricultural and Food Research Council. 1993. Energy and protein requirements of ruminants. An advisory manual prepared by the AFRC Technical Committee on Responses to Nutrients. Wallingford (CT): CAB Int.

Allen MS. 2000. Effects of diet on short-term regulation of feed intake by lactating dairy cattle. J Dairy Sci. 83:1598-1624.

[AOAC] Association of Official Analytical Chemists. 1990. Official methods of analysis. 15th ed. Arlington: AOAC.

Archimède H, Sauvant D, Schmidely P. 1997. Quantitative review of ruminal and total tract digestion of mixed diet organic matter and carbohydrates. Reprod Nutr Dev. 37:173-189.

Bach Knudsen KE, Eggum BO, Jacobsen I. 1987. Nutritive-value of Danish-grown barley varieties. 2. Effect of carbohydrate-composition on digestibility of energy and protein. J Cereal Sci. 6:187-195.

Blanch M, Calsamiglia S, Dilorenzo N, DiCostanzo A, Muetzel S, Wallace RJ. 2009. Physiological changes in rumen fermentation during acidosis induction and its control using a multivalent polyclonal antibody preparation in heifers. J Anim Sci. 87:1722-1730.

Brouwer E. 1965. Report of sub-committee on constants and factors. In: Blaxter KL, editor. Proceedings of the 3rd Symposium on Energy Metabolism. London (UK): Academic Press.

Calsamiglia S, Ferret A, Reynolds CK, Kristensen NB, Van Vuuren AM. 2010. Strategies for optimizing nitrogen use by ruminants. Animal. 4:1184-1196.

Carter RR, Grovum WL. 1990. A review of the physiological significance of hypertonic body fluids on feed intake and ruminal function: salivation, motility and microbes. J Anim Sci. 68:2811-2832.

Casali AO, Detmann E, Valadares Filho SC, Pereira JC, Henriques LT, Freitas SG, Paulino MF. 2008. Influence of incubation time and particles size on indigestible compounds contents in cattle feeds and faeces obtained by in situ procedures. Braz J Anim Sci. 37:335-342.

Chen XB, Gomes MJ. 1992. Estimation of microbial protein supply to sheep and cattle based on urinary excretion of purine derivatives: an overview of technical details. Aberdeen (Scotland): Rowett Research Institute/International Feed Research Unit.

D'Agosto M, Carneiro ME. 1999. Evaluation of lugol solution used for counting rumen ciliates. Rev Bras Zool. 16:725-729.

Dehority BA. 1984. Evaluation of subsampling and fixation procedures used for counting rumen protozoa. Appl Environ Microbiol. 48:182-185.

Denman SE, McSweeney CS. 2006. Development of a real-time PCR assay for monitoring anaerobic fungal and cellulolytic bacterial populations within the rumen. FEMS Microbiol Ecol. 58:572-582.

Denman SE, Tomkins NW, Mcsweeney CS. 2007. Quantitation and diversity analysis of ruminal methanogenic populations in response to the antimethanogenic compound bromochloromethane. FEMS Microbiol Ecol. 62:313-322.

Devries TJ, Schwaiger T, Beauchemin KA, Penner GB. 2014. Impact of severity of ruminal acidosis on feedsorting behaviour of beef cattle. Anim Prod Sci. 54:1238-1242.

Doreau M, Van Der Werf HM, Micol D, Dubroeucq H, Agabriel J, Rochette Y, Martin C. 2011. Enteric methane production and greenhouse gases balance of diets differing in concentrate in the fattening phase of a beef production system. J Anim Sci. 89:2518-2528.

Ellis JL, Kebreab E, Odongo NE, Mcbride BW, Okine EK, France J. 2007. Prediction of methane production from dairy and beef cattle. J Dairy Sci. 90:3456-3466.

Fenner H. 1965. Method for determining total volatile bases in rumen fluid by steam distillation. J Dairy Sci. 48:249-251.

Fernando SC, Purvis IHT, Najar FZ, Sukharnikov LO, Krehbiel CR, Nagaraja TG, Roe BA, Desilva U. 2010. Rumen microbial population dynamics during adaptation to a high-grain diet. Appl Environ Microbiol. 76:7482-7490.

Forbes JM. 1996. Integration of regulatory signals controlling forage intake in ruminants. J Anim Sci. 74:3029-3035. 
Franzolin R, Dehority BA. 2010. The role of $\mathrm{pH}$ on the survival of rumen protozoa in steers. Brazilian J Anim Sci. 39:2262-2267.

Fujihara T, Ørskov ER, Reeds PJ, Kyle DJ. 1987. The effect of protein infusion on urinary excretion of purine derivatives in ruminants nourished by intragastric nutrition. J Agric Sci. 109:7-12.

Goering HK, Van Soest PJ. 1970. Forage fibre analyses (apparatus, reagents, procedures, and some applications) Agriculture Handbook No 379. Washington (DC): Agricultural Research Service, USDA.

González LA, Manteca X, Calsamiglia S, Schwartzkopf-Genswein KS, Ferret A. 2012. Ruminal ácidosis in feedlot cattle: interplay between feed ingredients, rumen function and feeding behavior (a review). Anim Feed Sci Technol. 172:66-79.

Harvatine KJ, Allen MS. 2006. Effects of fatty acid supplements on ruminal and total tract nutrient digestion in lactating dairy cows. J Dairy Sci. 89:1092-1103.

Huhtanen P, Rinne M, Nousiainen J. 2007. Evaluation of the factors affecting silage intake of dairy cows: A revision of the relative silage dry-matter intake index. Animal. 1:758-770.

[IPCC] Intergovernmental Panel on Climate Change. 1996. Revised IPCC guidelines for national greenhouse gas inventories: reference manual. [Cited 2014 June 1]. Available from: www. ipccnggip.iges.or.jp/public/gl/invs1.html

Khafipour E, Li S, Plaizier JC, Krause DO. 2009. Rumen microbiome composition determined using two nutritional models of subacute ruminal acidosis. Appl Environ Microbiol. 75:71157124.

Kobayashi Y, Shinkai T, Koike S. 2008. Ecological and physiological shows that fibrobacter succinogenes is important in rumen fiber digestion-review. Folia Microbiol. 53:195-200.

Koike S, Kobayash Y. 2001. Development and use of competitive PCR assays for the rumen cellulolytic bacteria: Fibrobacter succinogenes, ruminococcus albus and ruminococcus flavefaciens. FEMS Microbiol Lett. 204:361-366.

Metzler-Zebeli BU, Schmitz-Esser S, Klevenhusen F, Podstatzky-Lichtenstein L, Wagner M, Zebeli Q. 2013. Grain-rich diets differently alter ruminal and colonic abundance of microbial populations and lipopolysaccharide in goats. Anaerobe. 20:65-73.

Murray RM, Bryant AM, Leng RA. 1976. Rates of production of methane in the rumen and large intestine of sheep. Br J Nutr. 36:1-14.

Naga MA, El-Shazly K. 1968. The metabolic characterization of the ciliate protozoon eudiplodinium medium from the rumen of buffalo. J Gen Microbiol. 53:305-315.

Nagaraja TG, Lechtenberg KF. 2007. Acidosis in feedlot cattle. Vet Clin North Am Food Anim Pract. 23:333-350.

Nagaraja TG, Titgemeyer EC. 2007. Ruminal acidosis in beef cattle: the current microbiological and nutritional outlook. J Dairy Sci. 90:E17-38.

Oliveira SG, Berchielli TT, Pedreira MN, Primavesi O, Frighetto R, Lima M. 2007. Effect of tannin levels in sorghum silage and concentrate supplementation on apparent digestibility and methane emission in beef cattle. Anim Feed Sci Technol. 135:236-248.

Ørskov ER, McDonald I. 1979. The estimation of protein degradability in the rumen from incubation measurements weighted according to rate of passage. J Agric Sci. 92:499-503.

Palmquist DL, Conrad HR. 1971. Origin of plasma fatty acids in lactating cows fed high grain or high fat diets. J Dairy Sci. 54:1025-1033.

Pina DS, Valadares Filho SC, Tedeschi LO, Barbosa AM, Valadares RFD. 2009. Influence of different levels of concentrate and ruminally undegraded protein on digestive variables in beef heifers. J Anim Sci. 87:1058-1067.

Ramirez HA, Nestor K, Tedeschi LO, Callaway TR, Dowd SE, Fernando SC, Kononoff PJ. 2012. The effect of brown midrib corn silage and dried distillers' grains with solubles on milk production, nitrogen utilization and microbial community structure in dairy cows. Can J Anim Sci. 92:365-380.

Ribeiro CS, Granja-Salcedo YT, Messana JD, Neto AJ, Canesin RC, Fiorentini G, Alarcon MF, Berchielli TT. 2015. Feeding increasing concentrate to Tifton 85 hay ratios modulated rumen fermentation and microbiota in Nellore feedlot steers. J Agric Sci. 153:1116-1127. 
Russell JB, Baldwin RL. 1978. Substrate preferences in rumen bacteria. evidence of catabolite regulatory mechanisms. J Appl Microbiol. 36:319-329.

Russell JB, Dombrowski DB. 1980. Effect of $\mathrm{pH}$ on the efficiency of growth by pure cultures of rumen bacteria in continuous culture. Appl Environ Microbiol. 39:604-610.

Russell JB, Sniffen CJ, Van Soest PJ. 1983. Effect of carbohydrate limitation on degradation and utilization of casein by mixed rumen bacteria. J Dairy Sci. 66:763-775.

Satter LD, Roffler RE. 1975. Nitrogen requirement and utilization in dairy cattle. J Dairy Sci. 58:1219-1237.

Sniffen CJ, O'connor JD, Van Soest PJ, Fox DJ, Russel JBA. 1992. Net carbohydrate and protein system for evaluating cattle diets: II. Carbohydrate and protein availability. J Anim Sci. 70:3562-3577.

Stewart CS, Flynt HJ, Bryant MP. 1997. The rumen bacteria. In: Hobson PN, Stewart CS, editors. The rumen microbial ecosystem. New York (NY): Blackie Academic and Professional.

Sutton JD, Dhanoa MS, Morant SV, France J, Napper DJ, Schuller E. 2003. Rates of production of acetate, propionate, and butyrate in the rumen of lactating dairy cows given normal and low-roughage diets. J Dairy Sci. 86:3620-3633.

Van Soest PJ, Robertson JB. 1985. Analysis of forages and fibrous foods. Ithaca (NY): Cornell University Press.

Van Soest PJ, Robertson JB, Lewis BA. 1991. Methods for dietary fibre, neutral detergent fibre and non-starch polysaccharides in relation to animal nutrition. J Dairy Sci. 74:3583-3597.

Wereszka K, Michałowski T. 2012. The ability of the rumen ciliate protozoan diploplastron affine to digest and ferment starch. Folia Microbiol. 57:375-377.

Yang WZ, Beauchemin KA. 2006. Physically effective fiber: method of determination and effects on chewing, ruminal acidosis, and digestion by dairy cows. J Dairy Sci. 89:2618-2633. 